Article

\title{
Comparative Strengths of Tetrel, Pnicogen, Chalcogen, and Halogen Bonds and Contributing Factors
}

\author{
Wenbo Dong ${ }^{1}$, Qingzhong $\mathrm{Li}^{1, *}$ and Steve Scheiner ${ }^{2, *(1)}$ \\ 1 The Laboratory of Theoretical and Computational Chemistry, School of Chemistry and Chemical \\ Engineering, Yantai University, Yantai 264005, China; dongwenbo1994@163.com \\ 2 Department of Chemistry and Biochemistry, Utah State University, Logan, UT 84322-0300, USA \\ * Correspondence: lqz@ytu.edu.cn (Q.L.); steve.scheiner@usu.edu (S.S.); \\ Tel.: +86-535-690-2063 (Q.L.); +1-435-797-7419 (S.S.)
}

Received: 29 June 2018; Accepted: 9 July 2018; Published: 10 July 2018

\begin{abstract}
Ab}$ initio calculations are employed to assess the relative strengths of various noncovalent bonds. Tetrel, pnicogen, chalcogen, and halogen atoms are represented by third-row atoms Ge, As, $\mathrm{Se}$, and $\mathrm{Br}$, respectively. Each atom was placed in a series of molecular bonding situations, beginning with all $\mathrm{H}$ atoms, then progressing to methyl substitutions, and $\mathrm{F}$ substituents placed in various locations around the central atom. Each Lewis acid was allowed to engage in a complex with $\mathrm{NH}_{3}$ as a common nucleophile, and the strength and other aspects of the dimer were assessed. In the context of fully hydrogenated acids, the strengths of the various bonds varied in the pattern of chalcogen $>$ halogen $>$ pnicogen $\approx$ tetrel. Methyl substitution weakened all bonds, but not in a uniform manner, resulting in a greatly weakened halogen bond. Fluorosubstitution strengthened the interactions, increasing its effect as the number of $\mathrm{F}$ atoms rises. The effect was strongest when the $\mathrm{F}$ atom lay directly opposite the base, resulting in a halogen $>$ chalcogen $>$ pnicogen $>$ tetrel order of bond strength. Replacing third-row atoms by their second-row counterparts weakened the bonds, but not uniformly. Tetrel bonds were weakest for the fully hydrogenated acids and surpassed pnicogen bonds when $\mathrm{F}$ had been added to the acid.
\end{abstract}

Keywords: halogen bond; chalcogen bond; pnicogen bond; tetrel bond

\section{Introduction}

A revolution of sorts, albeit a gradual one, occurred in the field of noncovalent interactions as it became progressively more apparent that the venerable $\mathrm{H}$-bond was not completely unique. That is, the bridging proton in $\mathrm{H}$-bonds could be replaced by a variety of other atoms, with little if any loss in noncovalent bond energy. The first class of atoms that fit this criterion was the halogens [1-10]. The ability of these very electronegative atoms to replace an $\mathrm{H}$ atom was deemed counterintuitive at first, as the polarity of the $\mathrm{R}-\mathrm{H}$ bond, placing a partial positive charge on the proton, was considered a prime ingredient of the classic H-bond. This issue was resolved when it was found that the charge distribution around the halogen atom in an analogous $\mathrm{R}-\mathrm{X}(\mathrm{X}=$ halogen) bond is highly asymmetric. While there is an equatorial band of negative electrostatic potential surrounding the $X$ atom in a $R-X$ bond, there is also a positive polar region situated directly opposite the $\mathrm{R}$ atom. This positive area, frequently referred to as a $\sigma$-hole, can attract an approaching nucleophile in precisely the same way the partially positive charge surrounding the proton of a H-bond can [11,12]. Of course, the interaction, whether an $\mathrm{H}$ or halogen bond, is not entirely electrostatic as it contains other elements, such as charge transfer and dispersion, but this charge distribution voided the argument that a halogen atom must necessarily repel an incoming nucleophile. 
As further work proceeded, it soon became apparent that this same phenomenon can be extended to more than just the halogen family of elements. Chalcogen atoms of the S/Se group could engage [13-21] in very similar bonding to a nucleophile. As these atoms are commonly involved in covalent bonding with two substituents, one would expect a pair of such $\sigma$-holes, one opposite each of these two substituents. Indeed, chalcogen bonding reflected this pattern, as there were two such sites that could engage in these interactions. Along similar lines of thinking, there ought to be three $\sigma$-holes surrounding a trivalent pnicogen atom, each of which is in principle capable of forming a so-called pnicogen bond, which has in fact been observed [22-27]. Tetrel atoms of the Si/Ge family, too, can participate [28-36] in analogously named bonds, and their most common tetravalent covalent bonding situation provides four separate sites for potential tetrel bonds.

These various noncovalent bond analogues of the H-bond share a number of characteristics [37-54]. For example, regardless of the particular family of atoms, as one moves down a column of the periodic table, the atom becomes progressively less electronegative and more polarizable. Both of these factors tend to amplify the $\sigma$-hole, and reinforce charge transfer from the nucleophile, and to thus strengthen the corresponding noncovalent bond. These same factors can also be intensified if electron-withdrawing substituents are added to the atom in question. Scores of previous results have accordingly demonstrated the ability of such substituents to strengthen the noncovalent bond to the approaching nucleophile. This effect is most pronounced when the substituent lies directly opposite the nucleophile, where it can better accommodate additional charge accumulation from the electron donor. Due to a strong electrostatic component in all of these bonds, they are dramatically strengthened if the Lewis acid is positively charged, with a like reinforcement upon interaction with an anion.

One issue that has borne only very moderate study is the comparison of these different noncovalent bonds with an eye toward those factors that differentiate one from another. While a substantial amount of work has compared each separate sort of bond with the prototype H-bond [55-70], much less is known about the strength of one with respect to another. On the face of it, one might think that the least electronegative atom is prone to form the most intense $\sigma$-holes, and that is in fact what is seen within any given family of atoms, e.g., the halogens or the chalcogens. This premise would lead to the general conclusion that the noncovalent bonding strength ought to increase in the order halogen $<$ chalcogen $<$ pnicogen < tetrel. However, a scan of the literature would suggest this is not the case. As another issue, in order to approach the pertinent atom, the nucleophile must avoid steric and repulsive electrostatic interactions with any of the substituents or lone electron pairs surrounding this central atom. As one proceeds along the halogen-to-tetrel series, the number of lone pairs diminishes while there is an increase in the number of substituents. This trend will also factor into the relative strengths of the different sorts of bonds.

At this juncture, then, there is a need for a thorough and fair comparison of the different sorts of noncovalent bonds. Can one make the general claim that one type will be stronger than another, given like covalent bonding situations? If this is found to be the case, then can one explain this trend on simple chemical grounds? In order to establish any such pattern, it is essential that the calculations be performed at a level that can be considered fully reliable, particularly if the differences in binding strength are small. The present work attempts to answer these questions using high-level $\mathrm{ab}$ initio calculations.

\section{Systems and Theoretical Methods}

In order to establish a valid and consistent baseline, focus was first placed on the third row of the periodic table where $\mathrm{Br}$ was compared with $\mathrm{Se}, \mathrm{As}$, and $\mathrm{Ge}$, as representative of halogen, chalcogen, pnicogen, and tetrel atoms, respectively. Each was placed in a variety of molecular environments, starting with all $\mathrm{H}$ substituents as a base point. In the next phase, one $\mathrm{H}$ atom was replaced by a methyl group, as a small representative alkyl chain to which many of these atoms would normally be attached. As electron-withdrawing groups are known to amplify each of these sorts of noncovalent bonds, $\mathrm{F}$ atoms were added in various modes. This atom could be added in a position directly opposite 
the nucleophile where it was thought to have the largest amplifying effect. As an alternative, to take advantage of its electron-withdrawing capability, but without its distortion of the $\sigma^{*}$ antibonding orbital that acts as a sink to electron density transferred from the nucleophile, the F atom could be placed in a peripheral position, viz. bonded to the atom in question, but not directly opposite the nucleophile. In order to assure that the results were not limited to only third-row atoms, additional calculations were carried out with their second-row counterparts. $\mathrm{NH}_{3}$ was taken as the universal nucleophilic partner, as its small size and presence of a single lone pair avoided the complications that might result from interactions other than the ones of interest.

The complexes and monomers were fully optimized using second-order Møller-Plesset perturbation theory (MP2) with the aug-cc-pVTZ basis set [71,72]. Harmonic vibrational frequencies were then computed at the same level in order to verify that the structures obtained correspond to minima with no imaginary frequencies and to obtain vibrational frequencies. Optimization and frequency calculations were carried out using the Gaussian 09 program [73]. Optimized coordinates of monomers and complexes are supplied in the Supplementary Materials section.

Interaction energy $\left(\mathrm{E}_{\mathrm{int}}\right)$ and binding energy $\left(\mathrm{E}_{\mathrm{b}}\right)$ were used as a measure of the strength of the interactions; they were calculated as the difference between the energy of the complex relative to the monomers in the complex geometry, and the optimized monomers, respectively. $\mathrm{E}_{\text {int }}$ was also computed with the CCSD(T) (Coupled Cluster with Single and Double Excitations, with Iterative Triples) method for the optimized MP2 structure. Both terms were corrected for basis set superposition error (BSSE) using the counterpoise procedure [74,75] outlined by Boys and Bernardi.

Molecular electrostatic potentials (MEPs) were computed on the 0.001 au electron density contour at the MP2/aug-cc-pVTZ level with the Wave Function Analysis-Surface Analysis-Suite (WFA-SAS) program [76]. The value of the MEP maximum of the $\sigma$-hole of the Lewis acid monomer facing the base was evaluated. The Natural Bond Orbital (NBO) method [77] was utilized to extract atomic charges and intermolecular orbital interactions between occupied and empty orbitals using the NBO-3.1 program, included within the Gaussian-09 program.

The bonding characteristics were analyzed by means of Atoms-in-Molecules (AIM) theory [78]. The relevant bond critical point (BCP) and topological parameters including electron density, Laplacian, and total electron energy density were obtained using the AIM2000 program [79]. To help understand the origin of the binding within each complex, the interaction energy was decomposed into five physically meaningful terms: electrostatic $\left(E^{e l e}\right)$, exchange $\left(E^{e x}\right)$, repulsion $\left(E^{r e p}\right)$, polarization $\left(E^{p o l}\right)$, and dispersion $\left(\mathrm{E}^{\text {disp}}\right)$. This decomposition was performed using the localized molecular orbital-energy decomposition analysis (LMO-EDA) method [80] at the MP2/aug-cc-pVTZ level via the GAMESS program [81].

\section{Results}

\subsection{Energies and Geometries}

The diagrams in Figure 1 correspond to the unsubstituted Lewis acids where all atoms bonded to the central A atom are $\mathrm{H}$. As displayed in the topmost section of Table 1, the MP2 interaction energies varied between -6.8 and $-9.1 \mathrm{~kJ} / \mathrm{mol}$, with the tetrel and chalcogen bonds being the weakest and strongest, respectively. Raising the level of calculation up to CCSD(T) had a small effect, changing these quantities by $0.2-0.4 \mathrm{~kJ} / \mathrm{mol}$. This higher-level treatment of correlation weakened all the bonds, with the exception of the tetrel bond, making it slightly stronger than the pnicogen bond. The MP2 binding energies in the third column of Table 1 were only slightly less negative than $\mathrm{E}_{\text {int }}$, a result of small deformation energies of the two monomers upon forming the complex. The intermolecular $\mathrm{R}(\mathrm{A} \cdots \mathrm{N})$ distances conformed roughly with the energy trends, although the halogen bond was the shortest, despite its being weaker than the chalcogen bond. This may have been partly due to the smaller covalent radius of Br. In terms of mutual orientations, both the halogen and tetrel bonds were fully linear, while the chalcogen and pnicogen bonds deviated by nearly $20^{\circ}$ from linearity. 

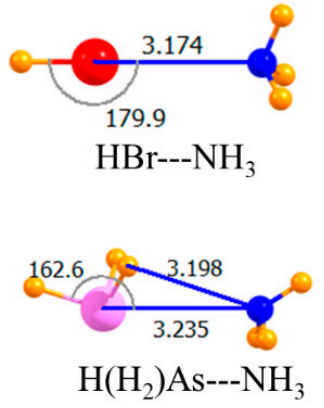
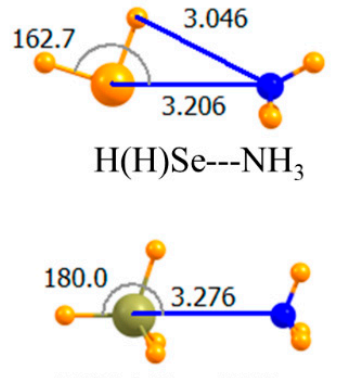

$\mathrm{H}\left(\mathrm{H}_{3}\right) \mathrm{Ge}---\mathrm{NH}_{3}$

Figure 1. Optimized geometries of complexes of non-fluorinated Lewis acids with $\mathrm{NH}_{3}$. Intermolecular distances are in $\AA$, angles in deg.

Table 1. Interaction energy $\left(E_{\text {int }}\right)$, binding energy $\left(E_{b}\right)$, intermolecular distance $(R, \AA)$, and angle $\theta(\mathrm{R}-\mathrm{A} \cdots \mathrm{N})(\mathrm{deg})$ where $\mathrm{R}$ represents the atom directly opposite $\mathrm{NH}_{3}$. Energies are in $\mathrm{kJ} / \mathrm{mol}$.

\begin{tabular}{|c|c|c|c|c|c|}
\hline Lewis Acid & $\mathrm{E}_{\mathrm{int}, \mathrm{MP2}}$ & $\mathrm{E}_{\mathrm{int}, \mathrm{CCSD}(\mathrm{T})}$ & $\mathrm{E}_{\mathrm{b}, \mathrm{MP} 2}$ & $\mathbf{R}$ & $\theta(\mathrm{R}-\mathrm{A} \cdots \mathrm{N})$ \\
\hline \multicolumn{6}{|c|}{$\mathrm{H}-\mathrm{H}_{\mathrm{n}} \mathrm{A}$} \\
\hline $\mathrm{HBr}$ & -7.79 & -7.57 & -7.77 & 3.174 & 179.9 \\
\hline $\mathrm{H}(\mathrm{H}) \mathrm{Se}$ & -9.08 & -8.68 & -8.98 & 3.206 & 162.7 \\
\hline $\mathrm{H}\left(\mathrm{H}_{2}\right) \mathrm{As}$ & -7.10 & -6.81 & -7.02 & 3.235 & 162.6 \\
\hline $\mathrm{H}\left(\mathrm{H}_{3}\right) \mathrm{Ge}$ & -6.83 & -7.07 & -6.42 & 3.276 & 180.0 \\
\hline \multicolumn{6}{|c|}{$\mathrm{Me}-\mathrm{H}_{\mathrm{n}} \mathrm{A}$} \\
\hline $\mathrm{MeBr}$ & -5.01 & -4.57 & -4.99 & 3.233 & 160.4 \\
\hline $\mathrm{Me}(\mathrm{H}) \mathrm{Se}$ & -7.90 & -7.50 & -7.82 & 3.234 & 166.6 \\
\hline $\mathrm{Me}\left(\mathrm{H}_{2}\right) \mathrm{As}$ & -6.27 & -6.09 & -6.19 & 3.268 & 168.5 \\
\hline $\mathrm{Me}\left(\mathrm{H}_{3}\right) \mathrm{Ge}$ & -5.29 & -5.71 & -4.90 & 3.329 & 179.7 \\
\hline \multicolumn{6}{|c|}{$\mathrm{H}-\mathrm{F}_{\mathrm{n}} \mathrm{A}$} \\
\hline $\mathrm{H}(\mathrm{F}) \mathrm{Se}$ & -14.43 & -14.08 & -13.89 & 3.023 & 161.6 \\
\hline $\mathrm{H}\left(\mathrm{F}_{2}\right) \mathrm{As}$ & -18.35 & -18.36 & -17.11 & 2.882 & 155.0 \\
\hline $\mathrm{H}\left(\mathrm{F}_{3}\right) \mathrm{Ge}$ & -120.73 & -122.35 & -35.04 & 2.101 & 180.0 \\
\hline \multicolumn{6}{|c|}{$\mathrm{Me}-\mathrm{F}_{\mathrm{n}} \mathrm{A}$} \\
\hline $\mathrm{Me}(\mathrm{F}) \mathrm{Se}$ & -11.86 & -11.66 & -11.46 & 3.114 & 162.7 \\
\hline $\mathrm{Me}\left(\mathrm{F}_{2}\right) \mathrm{As}$ & -14.44 & -14.73 & -13.64 & 3.021 & 155.3 \\
\hline $\mathrm{Me}\left(\mathrm{F}_{3}\right) \mathrm{Ge}$ & -111.65 & -111.27 & -25.77 & 2.115 & 180.0 \\
\hline \multicolumn{6}{|c|}{$\mathrm{F}-\mathrm{H}_{\mathrm{n}} \mathrm{A}$} \\
\hline $\mathrm{FBr}$ & -67.87 & -59.18 & -61.71 & 2.293 & 180.0 \\
\hline $\mathrm{F}(\mathrm{H}) \mathrm{Se}$ & -49.25 & -44.35 & -45.97 & 2.423 & 169.6 \\
\hline $\mathrm{F}\left(\mathrm{H}_{2}\right) \mathrm{As}$ & -34.57 & -32.30 & -32.76 & 2.597 & 165.3 \\
\hline $\mathrm{F}\left(\mathrm{H}_{3}\right) \mathrm{Ge}$ & -30.93 & -30.59 & -25.28 & 2.640 & 179.9 \\
\hline
\end{tabular}

Replacing the $\mathrm{H}$ atom that lay opposite the $\mathrm{NH}_{3}$ with a methyl group led to the geometries depicted in Figure 2. The only substantive reorientation induced by this methyl substitution involved the $\mathrm{Br}$ halogen wherein the $\mathrm{NH}_{3}$ came off of the $\mathrm{C}$ - $\mathrm{Br}$ axis by $20^{\circ}$, and its $\mathrm{C}_{3}$ axis turned away from the Br. This methylation weakened all of the bonds, but by varying amounts. This weakening was an expected consequence of the electron-releasing properties of this alkyl group. Using the $\operatorname{CCSD}(\mathrm{T})$ data as a reference, the pnicogen bond was weakened by only $0.7 \mathrm{~kJ} / \mathrm{mol}$, while the largest decrease of $3.0 \mathrm{~kJ} / \mathrm{mol}$ occurred for the halogen bond, consistent with its nonlinearity. The chalcogen bond remained the strongest of the four, and it was the halogen bond that was weakest for these methyl-substituted Lewis acids. This same pattern was carried over into the binding energies, which included geometric deformations of the monomers. Commensurate with the weakening of all bonds, the intermolecular distances were all a bit longer for $\mathrm{Me}-\mathrm{H}_{\mathrm{n}} \mathrm{A}$. Note also that this substitution induced a $20^{\circ}$ nonlinearity into the halogen bond, while slightly enhancing the linearity of the chalcogen and pnicogen bonds. 


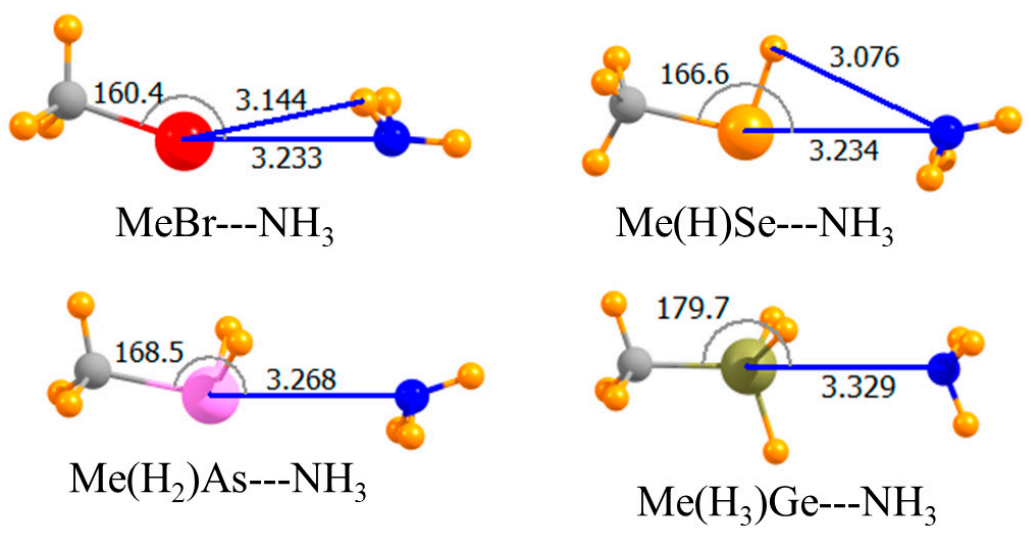

Figure 2. Optimized geometries of complexes of methyl Lewis acids with $\mathrm{NH}_{3}$. Intermolecular distances are in $\AA$, angles in deg.

The introduction of electron-withdrawing $\mathrm{F}$ atoms onto any given $\mathrm{A}$ atom is known to enhance its Lewis acidity. The next section of data in Table 1 relates to replacing all $\mathrm{H}$ atoms but the one that lay directly opposite the $\mathrm{NH}_{3}$ by $\mathrm{F}$. The molecular structures in Figure 3 indicated very nonlinear chalcogen and pnicogen bonds, with $\theta(\mathrm{HA} \cdots \mathrm{N})$ equal to $162^{\circ}$ and $155^{\circ}$, respectively. Despite this nonlinearity, this substitution substantially increased the strength of both these bonds. The interaction energy of the former rose by $6.6 \mathrm{~kJ} / \mathrm{mol}$, and the latter by $12.3 \mathrm{~kJ} / \mathrm{mol}$. The larger increment in the case of the pnicogen bond was likely due to the introduction of two $\mathrm{F}$ atoms rather than the single $\mathrm{F}$ atom for the chalcogen bond. Upon adding a third $\mathrm{F}$ atom, there was a dramatic change. The very large increase in the case of the tetrel bond, more than $100 \mathrm{~kJ} / \mathrm{mol}$, resulted from its transition into what might be better termed a covalent bond, or at least partially covalent. Note that the R(Ge $\cdots \mathrm{N})$ distance was only $2.1 \AA$, a contraction of more than a full $\AA$ in comparison to the previous two cases. This very close encounter cannot be established without substantial monomer deformation. That is, the three $\mathrm{F}$ atoms must have peeled back away from the approaching $\mathrm{N}$ as the $\mathrm{HGeF}_{3}$ molecule lost its initial pseudo-tetrahedral shape in forming the trigonal bipyramid that encompassed the fifth $\mathrm{NH}_{3}$ ligand. This distortion cost some $85 \mathrm{~kJ} / \mathrm{mol}$. The final binding energy $E_{b}$ of the tetrel bond was $35 \mathrm{~kJ} / \mathrm{mol}$, more than double that of the pnicogen bond, which is itself stronger than the chalcogen bond. As in the earlier case, switching out the $\mathrm{H}$ atom on the Lewis acid opposite the $\mathrm{NH}_{3}$ with a methyl group, as in Figure 4, weakened all of the interactions. This decrement in the binding energy was only $2-3 \mathrm{~kJ} / \mathrm{mol}$ for the chalcogen and pnicogen bonds, but amounted to $9 \mathrm{~kJ} / \mathrm{mol}$ for the tetrel analogue.

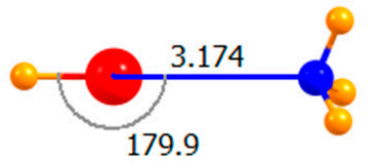

$\mathrm{HBr}---\mathrm{NH}_{3}$

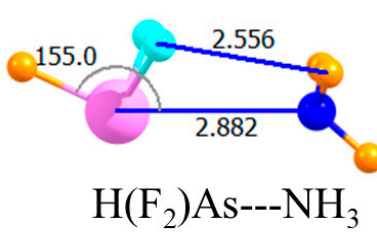

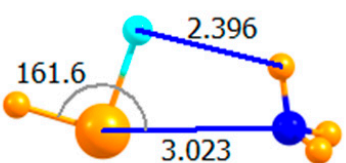

$\mathrm{H}(\mathrm{F}) \mathrm{Se}---\mathrm{NH}_{3}$

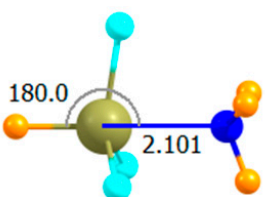

$\mathrm{H}\left(\mathrm{F}_{3}\right) \mathrm{Ge}---\mathrm{NH}_{3}$

Figure 3. Optimized geometries of complexes involving a partially fluorinated Lewis acid with $\mathrm{H}$ opposite N. Intermolecular distances are in $\AA$, angles in deg. 

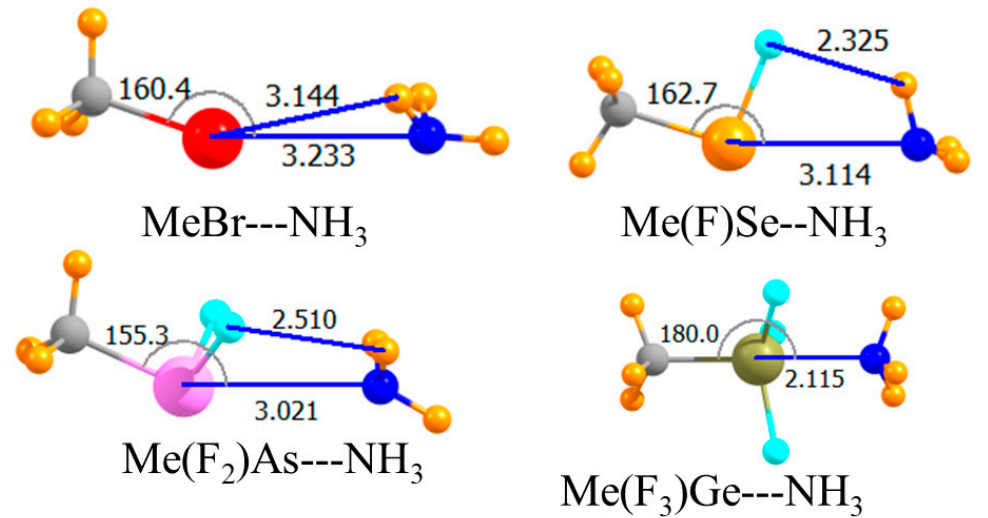

Figure 4. Optimized geometries of complexes involving a fluorinated Lewis acid with $\mathrm{CH}_{3}$ opposite N. Intermolecular distances are in $\AA$, angles in deg.

The placement of an electron-withdrawing $\mathrm{F}$ atom directly opposite the Lewis base is known to have an even stronger effect than when it is peripherally located. The molecular structures in Figure 5 show again that the halogen and tetrel bonds remained linear, reflecting the symmetry of the Lewis acids, while the less symmetrical chalcogen and pnicogen bonds were substantially distorted from linearity, with the $\mathrm{NH}_{3}$ moving up and closer to the $\mathrm{H}$ atom(s) of the acid. The bottom section of Table 1 shows the very large binding magnifications quite clearly. Note first that when the $\mathrm{F}$ atom was so positioned on the Ge atom, Ge did not engage in a covalent bond with the $\mathrm{NH}_{3}$. Indeed, the tetrel bond was the weakest of the array, which followed the pattern halogen $>$ chalcogen $>$ pnicogen $>$ tetrel. This order was a very clear one, with fairly large differences between one bond type and another. Moreover, this pattern was valid not only for $\mathrm{E}_{\mathrm{b}}$, but for the interaction energy as well. One also saw a clear correlation in that stronger bonds were connected by the shortest intermolecular separations. It might be noted parenthetically that with the $\mathrm{F}$ atom opposite the $\mathrm{NH}_{3}$, Ge did not engage in a covalent bond with the base, with $\mathrm{R}(\mathrm{Ge} \cdots \mathrm{N})=2.64 \AA$.
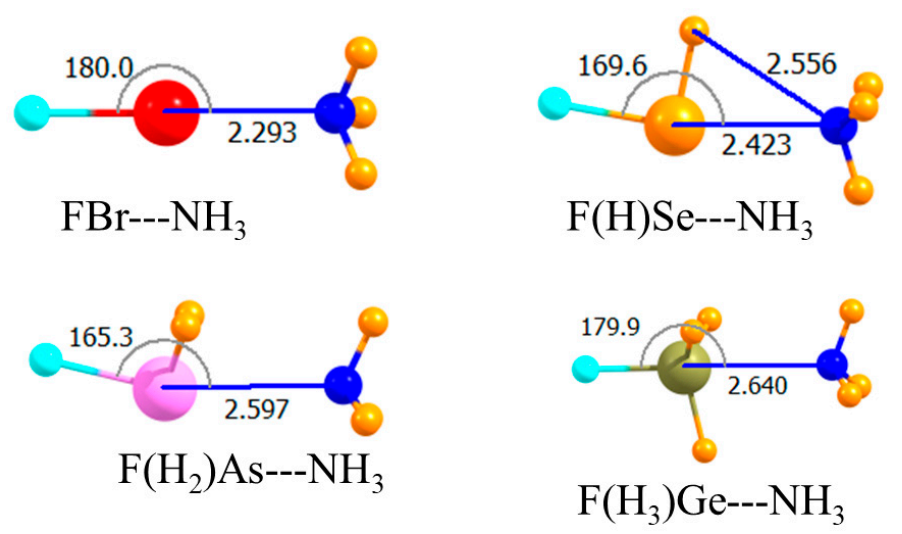

Figure 5. Optimized geometries of complexes involving a partially mono-fluorinated Lewis acid with one $\mathrm{F}$ atom opposite N. Intermolecular distances are in $\AA$, angles in deg.

\subsection{Analysis of the Wave Functions}

There are a number of factors that contribute to the strength of noncovalent bonds of this type. As a component of the electrostatic attraction, one typically observes the presence of a so-called $\sigma$-hole on the A atom of the Lewis acid. This hole occurs directly opposite one of the covalent bonds in which the A atom is engaged, and attracts the Lewis base. The intensity of this hole is commonly measured by the value of the molecular electrostatic potential (MEP) on a particular isodensity surface, usually 
taken arbitrarily as $\rho=0.001$ au. This maximum, labeled $V_{s, m a x}$, is reported in the second column of Table 2 for each of the Lewis acid monomers. There are certain points of similarity between these MEP maxima and the interaction energies in Table 1. Taking the $\mathrm{F}-\mathrm{H}_{\mathrm{n}} \mathrm{A}$ acids as an example, the values of $\mathrm{V}_{\mathrm{s} \text {, max }}$ followed the same halogen $>$ chalcogen $>$ pnicogen $>$ tetrel order as does $\mathrm{E}_{\mathrm{int}}$, and both exhibited the same (opposite) pattern of tetrel $>$ pnicogen $>$ chalcogen for the H-F $\mathrm{A}$ acids. However, there are inconsistencies as well. For example, the replacement of the $\mathrm{H}$ atom of $\mathrm{HBr}$ by a methyl group reduced the interaction energy while intensifying its $\sigma$-hole. Even though $\mathrm{H}\left(\mathrm{H}_{3}\right) \mathrm{Ge}$ formed the weakest of this class of bonds, it also presented the largest $\mathrm{V}_{\mathrm{s}, \max }$.

Table 2. MEP maximum $\left(\mathrm{V}_{\mathrm{s}, \max }\right)$ of the $\sigma$-hole of the acid monomer facing the base, total charge transfer (CT) from the Lewis base to the acid, $\mathrm{NBO}$ values of $\mathrm{E}(2)$ from the $\mathrm{N}$ lone pair of $\mathrm{NH}_{3}$ to $\sigma^{*}(\mathrm{~A}-\mathrm{R})$ antibonding orbitals where $\mathrm{A}$ is the central atom of the Lewis acid and $\mathrm{R}$ is (a) the atom directly opposite $\mathrm{N}$ and (b) the peripheral atom(s). Also shown is change in A-R bond length $(\Delta \mathrm{r})$ and vibrational frequency $(\Delta v)$ of the A-R stretch, where R lies opposite $\mathrm{N}$.

\begin{tabular}{|c|c|c|c|c|c|c|}
\hline Lewis Acid & $\begin{array}{c}\mathrm{V}_{\mathrm{s}, \max } \\
\mathrm{au}\end{array}$ & $\begin{array}{l}\text { CT } \\
\text { me }\end{array}$ & $\begin{array}{c}\mathrm{E}(2)^{\mathrm{a}} \\
\mathrm{kcal} / \mathrm{mol}\end{array}$ & $\begin{array}{c}\mathrm{E}(2)^{\mathrm{b}} \\
\mathrm{kcal} / \mathrm{mol}\end{array}$ & $\begin{array}{c}\Delta \mathrm{r}(\mathrm{A}-\mathrm{R}) \\
\AA\end{array}$ & $\begin{array}{c}\Delta v(\mathrm{~A}-\mathrm{R}) \\
\mathrm{cm}^{-1}\end{array}$ \\
\hline \multicolumn{7}{|c|}{$\mathrm{H}-\mathrm{H}_{\mathrm{n}} \mathrm{A}$} \\
\hline $\mathrm{HBr}$ & 0.027 & 2 & 11.37 & - & 0.004 & -26.8 \\
\hline $\mathrm{H}(\mathrm{H}) \mathrm{Se}$ & 0.030 & 4 & 8.99 & 0.54 & 0.003 & -107.6 \\
\hline $\mathrm{H}\left(\mathrm{H}_{2}\right) \mathrm{As}$ & 0.028 & 7 & 10.70 & 2.51 & 0.006 & -5.4 \\
\hline $\mathrm{H}\left(\mathrm{H}_{3}\right) \mathrm{Ge}$ & 0.032 & 9 & 12.37 & 6.65 & 0.008 & +1.2 \\
\hline \multicolumn{7}{|c|}{$\mathrm{Me}-\mathrm{H}_{\mathrm{n}} \mathrm{A}$} \\
\hline $\mathrm{MeBr}$ & 0.030 & 1 & 3.26 & - & 0.001 & -1.3 \\
\hline $\mathrm{Me}(\mathrm{H}) \mathrm{Se}$ & 0.018 & 2 & 5.10 & 0.25 & 0.001 & -0.7 \\
\hline $\mathrm{Me}\left(\mathrm{H}_{2}\right) \mathrm{As}$ & 0.019 & 4 & 7.77 & 1.67 & 0.003 & -2.2 \\
\hline $\mathrm{Me}\left(\mathrm{H}_{3}\right) \mathrm{Ge}$ & 0.024 & 8 & 11.87 & 5.02 & 0.007 & -10.1 \\
\hline \multicolumn{7}{|c|}{$\mathrm{H}-\mathrm{F}_{\mathrm{n}} \mathrm{A}$} \\
\hline $\mathrm{H}(\mathrm{F}) \mathrm{Se}$ & 0.036 & 8 & 14.00 & 4.26 & 0.007 & -38.1 \\
\hline $\mathrm{H}\left(\mathrm{F}_{2}\right) \mathrm{As}$ & 0.046 & 27 & 15.34 & 14.46 & 0.009 & -44.8 \\
\hline $\mathrm{H}\left(\mathrm{F}_{3}\right) \mathrm{Ge}$ & 0.069 & 175 & 86.19 & 416.95 & 0.017 & -2.2 \\
\hline \multicolumn{7}{|c|}{$\mathrm{Me}-\mathrm{F}_{\mathrm{n}} \mathrm{A}$} \\
\hline $\mathrm{Me}(\mathrm{F}) \mathrm{Se}$ & 0.022 & 5 & 8.95 & 2.63 & 0.005 & -6.7 \\
\hline $\mathrm{Me}\left(\mathrm{F}_{2}\right) \mathrm{As}$ & 0.033 & 7 & 8.03 & 7.65 & 0.009 & -35.7 \\
\hline $\mathrm{Me}\left(\mathrm{F}_{3}\right) \mathrm{Ge}$ & 0.055 & 172 & 80.47 & 417.54 & 0.021 & -101.6 \\
\hline \multicolumn{7}{|c|}{$\mathrm{F}-\mathrm{H}_{\mathrm{n}} \mathrm{A}$} \\
\hline $\mathrm{FBr}$ & 0.093 & 143 & 255.40 & - & 0.070 & -114.9 \\
\hline $\mathrm{F}(\mathrm{H}) \mathrm{Se}$. & 0.089 & 90 & 152.82 & 11.03 & 0.049 & -107.6 \\
\hline $\mathrm{F}\left(\mathrm{H}_{2}\right) \mathrm{As}$ & 0.079 & 53 & 82.81 & 14.96 & 0.033 & -60.2 \\
\hline $\mathrm{F}\left(\mathrm{H}_{3}\right) \mathrm{Ge}$ & 0.077 & 46 & 59.11 & 39.12 & 0.027 & -63.3 \\
\hline
\end{tabular}

In addition to Coulombic attraction between the two monomers, the noncovalent bond depends on a certain amount of intermolecular charge transfer. One way to measure this quantity is as a summation of NBO atomic charges on the atoms of each subunit. This total charge transfer is displayed in the third column of Table 2. Like $\mathrm{V}_{\mathrm{s} \text {, max }}, \mathrm{CT}$ also correlated generally with the interaction energies. The replacement of one $\mathrm{H}$ atom by $\mathrm{CH}_{3}$ depressed both quantities, and both were substantially elevated by F-substitution. CT correctly predicted the energetic ordering of the noncovalent bond strengths of the $\mathrm{F}-\mathrm{H}_{\mathrm{n}} \mathrm{A}$ acids. However, like the MEP maxima, CT failed to correlate with the interaction energies of the non-fluorinated species.

Charge transfer can be understood not only as that between the two molecules as a whole, but also between individual molecular orbitals. The bulk of the charge originates in the $\mathrm{N}$ lone pair of $\mathrm{NH}_{3}$ that is pointing toward the acid. Its principal sink is the $\sigma^{*}$ antibonding orbital of the A-R $\mathrm{R}_{\mathrm{a}}$ bond wherein $R_{a}$ lies opposite the $\mathrm{N}$ atom. The energetic consequence of this particular charge transfer was 
calculated by the NBO procedure, and is reported as $\mathrm{E}(2)^{\mathrm{a}}$ in Table 2 . A second portion of the charge originating in the $\mathrm{N}$ lone pair made its way into the other $\sigma^{*}\left(A-R_{b}\right)$ antibonding orbitals, where $R_{b}$ refers to the peripheral substituents on $\mathrm{A}$, those not opposite the $\mathrm{N}$ atom. The cumulative sum of these transfers is tabulated as $\mathrm{E}(2)^{\mathrm{b}}$ in the fifth column of Table 2. Like the full CT, these individual components only partially reflected the energetics. Methyl substitution correctly reduced E(2), while fluorination led to a marked enhancement. $\mathrm{E}(2)^{\mathrm{a}}$ followed the same trend, as does the energetics for the $\mathrm{F}-\mathrm{H}_{\mathrm{n}} \mathrm{A}$ series. However, $\mathrm{E}(2)$ was largest for $\mathrm{H}\left(\mathrm{H}_{3}\right) \mathrm{Ge}$ and smallest for $\mathrm{H}(\mathrm{H}) \mathrm{Se}$, opposite to the trend in the interaction energies. Clearly, then, while consideration of the MEP and aspects of charge transfer bear some relation to the energetics, neither could be treated as fully predictive.

On the other hand, this charge transfer into the $\sigma^{*}\left(\mathrm{~A}-\mathrm{R}_{\mathrm{a}}\right)$ antibonding orbital afforded a reasonable indicator of the properties of this bond. The accumulation of additional charge in this antibonding orbital caused the A- $R_{a}$ bond to weaken, and hence to stretch. This elongation is displayed in the penultimate column of Table 2 and appeared to rise and fall in parallel with $\mathrm{E}(2)^{\mathrm{a}}$. For example, the longest stretch for most of the acids in the top sections of Table 2 occurred for Ge, as does the largest value of $\mathrm{E}(2)^{\mathrm{a}}$. The exception to this rule corresponded to those acids in the bottom section of Table 2 where a $\mathrm{F}$ atom sat directly opposite the $\mathrm{NH}_{3}$ base. In these cases, $\mathrm{E}(2)^{\mathrm{a}}$ followed the decreasing trend $\mathrm{Br}>\mathrm{Se}>\mathrm{As}>\mathrm{Ge}$, as did $\Delta \mathrm{r}$. Indeed, there was a tight correlation between these two quantities. The correlation coefficient for a linear relationship between $\Delta \mathrm{r}$ and $\mathrm{E}(2)^{\mathrm{a}}$ was 0.974 , which improved to 0.984 upon eliminating the two Ge systems that engage in a covalent bond.

The last column of Table 2 displays the stretching frequency of this same covalent bond, which shifted to the red in most instances, consistent with its elongation. However, correlations with other parameters were much weaker. For example, even though the charge transfer was quite modest in the complex between $\mathrm{H}(\mathrm{H})$ Se and $\mathrm{NH}_{3}$, and the binding energy was rather small, the pertinent $\mathrm{Se}-\mathrm{H}$ bond shifted by a full $108 \mathrm{~cm}^{-1}$ to the red, the largest shift of any of these complexes. The A-F red shifts in the $\mathrm{F}\left(\mathrm{H}_{2}\right)$ As and $\mathrm{F}\left(\mathrm{H}_{3}\right) \mathrm{Ge}$ complexes were the reverse of the energetic quantities of these two dimers. One must recall, however, that unlike a particular bond length, the normal vibrational modes did not isolate any one particular bond. Instead they coupled together a number of different bonds, some stretched while others contracted, and included some degree of bending as well. Given this complicated character, it was not surprising to see poor correlation between frequency shifts and other parameters.

The properties of the AIM bond critical point generally offer an accurate barometer of the strength of a noncovalent bond. The three most widely used such quantities are collected in Table 3 , and they bore some similarities with energetics. Methyl substitution reduced these values, while they increase upon fluorosubstitution. With respect to the F- $\mathrm{H}_{\mathrm{n}} \mathrm{A}$ acids, both $\rho$ and $\nabla^{2} \rho$ correctly reproduced the halogen $>$ chalcogen $>$ pnicogen $>$ tetrel energetic trend. However, AIM did not accurately reflect some of the other trends. Taking the unsubstituted $\mathrm{H}-\mathrm{H}_{n} \mathrm{~A}$ acids as a case in point, neither $\rho$ nor $\mathrm{H}$ displayed much differentiation from one type of bond to the next. The values of $\nabla^{2} \rho$ were somewhat different from one another, but seemed to exaggerate the strength of the halogen bond.

It is worthwhile to inquire as to how these four sorts of noncovalent bonds compare in terms of their basic contributing factors. Decomposition of the total interaction energy into electrostatic $\left(\mathrm{E}^{\mathrm{ele}}\right)$, exchange $\left(E^{e x}\right)$, repulsion ( $\left.E^{\text {rep }}\right)$, polarization $\left(E^{p o l}\right)$, and dispersion $\left(E^{\text {disp }}\right)$ provides a fingerprint of sorts for each interaction. These components are listed in Table 4 and show first for the nonfluorinated acids, that the electrostatic attraction was roughly twice that of dispersion, but there was little to distinguish one sort of bond from another in these two elements. On the other hand, exchange was roughly three times larger for the pnicogen and tetrel bonds, as compared to halogen and chalcogen. It was this outsized exchange energy which appeared to be a hallmark of the latter two types of bonds, regardless of substitution. Polarization energy represented the smallest component. With the exception of dispersion, which undergoes a small uptick, all of the other components were lowered upon methyl substitution. Even larger increments accompanied the replacement of one or more $\mathrm{H}$ atoms by $\mathrm{F}$. This fluorosubstitution raised the polarization energy to the point where it exceeded dispersion, and could become competitive with the exchange energy for the halogen and chalcogen bonds. 
Table 3. Electron density $(\rho)$, Laplacian $\left(\nabla^{2} \rho\right)$, and energy density $(H)$ at the intermolecular BCP in the complexes (all are in au).

\begin{tabular}{cccc}
\hline Lewis Acid & $\boldsymbol{\rho}$ & $\boldsymbol{\nabla}^{2} \boldsymbol{\rho}$ & $\mathbf{H}$ \\
\hline \multicolumn{4}{c}{$\mathrm{H}-\mathrm{H}_{\mathrm{n}} \mathrm{A}$} \\
$\mathrm{HBr}$ & 0.010 & 0.038 & 0.002 \\
$\mathrm{H}(\mathrm{H}) \mathrm{Se}$ & 0.009 & 0.034 & 0.001 \\
$\mathrm{H}\left(\mathrm{H}_{2}\right) \mathrm{As}$ & 0.009 & 0.029 & 0.001 \\
$\mathrm{H}\left(\mathrm{H}_{3}\right) \mathrm{Ge}$ & 0.008 & 0.025 & 0.001 \\
\hline \multicolumn{5}{c}{$\mathrm{Me}-\mathrm{H}_{\mathrm{n}} \mathrm{A}$} \\
\hline $\mathrm{MeBr}$ & 0.008 & 0.034 & 0.002 \\
$\mathrm{Me}(\mathrm{H}) \mathrm{Se}$ & 0.008 & 0.032 & 0.002 \\
$\mathrm{Me}\left(\mathrm{H}_{2}\right) \mathrm{As}$ & 0.008 & 0.027 & 0.001 \\
$\mathrm{Me}\left(\mathrm{H}_{3}\right) \mathrm{Ge}$ & 0.007 & 0.023 & 0.001 \\
\hline \multicolumn{5}{c}{$\mathrm{H}-\mathrm{F}_{\mathrm{n}} \mathrm{A}$} \\
\hline $\mathrm{H}(\mathrm{F}) \mathrm{Se}$ & 0.014 & 0.046 & 0.001 \\
$\mathrm{H}\left(\mathrm{F}_{2}\right) \mathrm{As}$ & 0.018 & 0.046 & 0.000 \\
$\mathrm{H}\left(\mathrm{F}_{3}\right) \mathrm{Ge}$ & 0.077 & 0.216 & -0.030 \\
\hline \multicolumn{5}{c}{$\mathrm{Me}-\mathrm{F}_{\mathrm{n}} \mathrm{A}$} \\
\hline $\mathrm{Me}(\mathrm{F}) \mathrm{Se}$ & 0.011 & 0.039 & 0.002 \\
$\mathrm{Me}\left(\mathrm{F}_{2}\right) \mathrm{As}$ & 0.013 & 0.037 & 0.001 \\
$\mathrm{Me}\left(\mathrm{F}_{3}\right) \mathrm{Ge}$ & 0.075 & 0.209 & -0.028 \\
\hline \multicolumn{5}{c}{$\mathrm{F}-\mathrm{H}_{\mathrm{n}} \mathrm{A}$} \\
$\mathrm{FBr}$ & 0.061 \\
$\mathrm{~F}(\mathrm{H}) \mathrm{Se} \cdot$ & 0.044 & 0.132 & -0.015 \\
$\mathrm{~F}\left(\mathrm{H}_{2}\right) \mathrm{As}$ & 0.029 & 0.074 & -0.007 \\
$\mathrm{~F}\left(\mathrm{H}_{3}\right) \mathrm{Ge}$ & 0.023 & 0.072 & 0.000 \\
\hline \multicolumn{5}{c}{}
\end{tabular}

Table 4. Electrostatic $\left(E^{\mathrm{ele}}\right)$, exchange $\left(E^{\mathrm{ex}}\right)$, repulsion $\left(E^{\mathrm{rep}}\right)$, polarization $\left(E^{\mathrm{pol}}\right)$, dispersion $\left(E^{\text {disp}}\right)$, and interaction energies $\left(\mathrm{E}_{\mathrm{int}}\right)$; all are in $\mathrm{kJ} / \mathrm{mol}$.

\begin{tabular}{|c|c|c|c|c|c|c|}
\hline Lewis Acid & E $^{\text {ele }}$ & $E^{e x}$ & $\mathrm{E}^{\text {rep }}$ & $E^{\text {pol }}$ & $E^{\text {disp }}$ & $E_{\text {int }}$ \\
\hline \multicolumn{7}{|c|}{$\mathrm{H}-\mathrm{H}_{\mathrm{n}} \mathrm{A}$} \\
\hline $\mathrm{HBr}$ & -16.30 & -10.29 & 49.53 & -4.81 & -7.27 & -7.90 \\
\hline $\mathrm{H}(\mathrm{H}) \mathrm{Se}$ & -16.85 & -10.29 & 48.61 & -4.14 & -7.69 & -9.11 \\
\hline $\mathrm{H}\left(\mathrm{H}_{2}\right) \mathrm{As}$ & -16.18 & -32.02 & 52.88 & -4.43 & -7.40 & -7.15 \\
\hline $\mathrm{H}\left(\mathrm{H}_{3}\right) \mathrm{Ge}$ & -16.80 & -32.65 & 53.63 & -4.64 & -6.40 & -6.86 \\
\hline \multicolumn{7}{|c|}{$\mathrm{Me}-\mathrm{H}_{\mathrm{n}} \mathrm{A}$} \\
\hline $\mathrm{MeBr}$ & -8.15 & -7.53 & 35.57 & -2.34 & -8.78 & -5.02 \\
\hline $\mathrm{Me}(\mathrm{H}) \mathrm{Se}$ & -12.79 & -9.04 & 42.39 & -3.18 & -8.74 & -7.86 \\
\hline $\mathrm{Me}\left(\mathrm{H}_{2}\right) \mathrm{As}$ & -13.00 & -28.72 & 47.23 & -3.55 & -8.23 & -6.31 \\
\hline $\mathrm{Me}\left(\mathrm{H}_{3}\right) \mathrm{Ge}$ & -13.29 & -29.59 & 48.03 & -4.14 & -6.40 & -5.35 \\
\hline \multicolumn{7}{|c|}{$\mathrm{H}-\mathrm{F}_{\mathrm{n}} \mathrm{A}$} \\
\hline $\mathrm{H}(\mathrm{F}) \mathrm{Se}$ & -34.19 & -19.00 & 93.92 & -9.91 & -10.66 & -14.50 \\
\hline $\mathrm{H}\left(\mathrm{F}_{2}\right) \mathrm{As}$ & -55.05 & -83.77 & 149.44 & -17.56 & -11.58 & -18.52 \\
\hline $\mathrm{H}\left(\mathrm{F}_{3}\right) \mathrm{Ge}$ & -363.74 & -371.98 & 782.50 & -165.65 & -2.17 & -121.05 \\
\hline \multicolumn{7}{|c|}{$\mathrm{Me}-\mathrm{F}_{\mathrm{n}} \mathrm{A}$} \\
\hline $\mathrm{Me}(\mathrm{F}) \mathrm{Se}$ & -25.67 & -15.70 & 76.37 & -7.44 & -10.87 & -11.95 \\
\hline $\mathrm{Me}\left(\mathrm{F}_{2}\right) \mathrm{As}$ & -36.91 & -59.31 & 103.54 & -10.41 & -11.50 & -14.59 \\
\hline $\mathrm{Me}\left(\mathrm{F}_{3}\right) \mathrm{Ge}$ & -352.88 & -369.72 & 773.13 & -158.21 & -4.31 & -111.94 \\
\hline \multicolumn{7}{|c|}{$\mathrm{F}-\mathrm{H}_{\mathrm{n}} \mathrm{A}$} \\
\hline $\mathrm{FBr}$ & -197.84 & -97.95 & 554.14 & -120.05 & -27.67 & -68.09 \\
\hline $\mathrm{F}(\mathrm{H}) \mathrm{Se}$ & -146.89 & -75.42 & 407.59 & -74.03 & -23.12 & -49.49 \\
\hline $\mathrm{F}\left(\mathrm{H}_{2}\right) \mathrm{As}$ & -98.61 & -147.64 & 269.90 & -40.67 & -17.85 & -34.86 \\
\hline $\mathrm{F}\left(\mathrm{H}_{3}\right) \mathrm{Ge}$ & -89.20 & -125.82 & 228.60 & -31.27 & -13.42 & -31.10 \\
\hline
\end{tabular}




\subsection{2nd Row Atoms}

It would be injudicious to base all conclusions concerning the comparisons between the various sorts of noncovalent bonds upon atoms in a single row (the third) of the periodic table. Thus, similar calculations were performed for the analogous atoms of the preceding row. The energetic and geometrical data for the complexes of these Lewis acids with $\mathrm{NH}_{3}$ are presented in Table 5, which may be directly compared with those in Table 1. It would be expected that the smaller size of the second-row atoms, coupled with their greater electronegativity, ought to have weakened their complexes with $\mathrm{NH}_{3}$. This trend was indeed observed, but with some exceptions. For example, the halogen bond of $\mathrm{HCl}$ was weaker than that of $\mathrm{HBr}$, but the tetrel bond of $\mathrm{H}\left(\mathrm{H}_{3}\right) \mathrm{Si}$ was stronger than its third row congener; this same trend was noted after methyl substitution as well. Another issue arises with $\mathrm{S}$. This atom was electronegative enough that it would not engage in a chalcogen bond with $\mathrm{NH}_{3}$. Instead, the $\mathrm{H}_{2} \mathrm{~S}$ molecule rotated around to form a SH$\cdots \mathrm{N} \mathrm{H}$-bond, as does MeSH.

Table 5. Interaction energy $\left(E_{\text {int }}\right)$, binding energy $\left(E_{b}\right)$, intermolecular distance $(R, \AA)$, and angle $\theta(\mathrm{R}-\mathrm{A} \cdots \mathrm{N})(\mathrm{deg})$ where R represents the atom directly opposite N. Energies are in $\mathrm{kJ} / \mathrm{mol}$.

\begin{tabular}{|c|c|c|c|c|c|}
\hline Lewis Acid & $\mathrm{E}_{\text {int, }} \mathrm{MP2}$ & $\mathrm{E}_{\mathrm{int}, \mathrm{CCSD}(\mathrm{T})}$ & $\mathrm{E}_{\mathrm{b}, \mathrm{MP} 2}$ & $\mathbf{R}$ & $\theta(\mathrm{R}-\mathrm{A} \cdots \mathrm{N})$ \\
\hline \multicolumn{6}{|c|}{$\mathrm{H}-\mathrm{H}_{\mathrm{n}} \mathrm{A}$} \\
\hline $\mathrm{HCl}$ & -3.77 & -3.73 & -3.77 & 3.254 & 156.5 \\
\hline $\mathrm{H}(\mathrm{H}) \mathrm{S}^{\mathrm{a}}$ & - & - & - & - & - \\
\hline $\mathrm{H}\left(\mathrm{H}_{2}\right) \mathrm{P}$ & -7.01 & -6.47 & -6.94 & 3.281 & 166.3 \\
\hline $\mathrm{H}\left(\mathrm{H}_{3}\right) \mathrm{Si}$ & -8.75 & -8.87 & -8.05 & 3.187 & 180.0 \\
\hline \multicolumn{6}{|c|}{$\mathrm{Me}-\mathrm{H}_{\mathrm{n}} \mathrm{A}$} \\
\hline $\mathrm{MeCl}$ & -4.01 & -3.81 & -3.98 & 3.409 & 145.2 \\
\hline $\operatorname{Me}(\mathrm{H}) \mathrm{S}^{\mathrm{a}}$ & - & - & - & - & - \\
\hline $\mathrm{Me}\left(\mathrm{H}_{2}\right) \mathrm{P}$ & -6.57 & -6.42 & -6.50 & 3.294 & 171.2 \\
\hline $\mathrm{Me}\left(\mathrm{H}_{3}\right) \mathrm{Si}$ & -6.38 & -6.74 & -5.77 & 3.257 & 180.0 \\
\hline \multicolumn{6}{|c|}{$\mathrm{H}-\mathrm{F}_{\mathrm{n}} \mathrm{A}$} \\
\hline $\mathrm{H}(\mathrm{F}) \mathrm{S}$ & -11.12 & -9.11 & -8.82 & 3.176 & 164.0 \\
\hline $\mathrm{H}\left(\mathrm{F}_{2}\right) \mathrm{P}$ & -11.41 & -11.79 & -10.93 & 3.051 & 159.0 \\
\hline $\mathrm{H}\left(\mathrm{F}_{3}\right) \mathrm{Si}$ & -106.23 & -108.75 & -17.19 & 2.099 & 180.0 \\
\hline \multicolumn{6}{|c|}{$\mathrm{Me}-\mathrm{F}_{\mathrm{n}} \mathrm{A}$} \\
\hline $\mathrm{Me}(\mathrm{F}) \mathrm{S}$ & -7.09 & -7.29 & -6.92 & 3.315 & 164.2 \\
\hline $\mathrm{Me}\left(\mathrm{F}_{2}\right) \mathrm{P}$ & -8.25 & -8.84 & -7.95 & 3.247 & 157.0 \\
\hline $\mathrm{Me}\left(\mathrm{F}_{3}\right) \mathrm{Si}$ & -12.06 & -13.51 & -7.57 & 3.086 & 179.8 \\
\hline \multicolumn{6}{|c|}{$\mathrm{F}-\mathrm{H}_{\mathrm{n}} \mathrm{A}$} \\
\hline $\mathrm{FCl}$ & -53.34 & -43.90 & -45.78 & 2.231 & 180.0 \\
\hline $\mathrm{F}(\mathrm{H}) \mathrm{S}$ & -37.36 & -33.14 & -34.98 & 2.435 & 171.0 \\
\hline $\mathrm{F}\left(\mathrm{H}_{2}\right) \mathrm{P}$ & -28.34 & -26.42 & -27.12 & 2.604 & 167.7 \\
\hline $\mathrm{F}\left(\mathrm{H}_{3}\right) \mathrm{Si}$ & -35.26 & -34.76 & -25.01 & 2.489 & 180.0 \\
\hline
\end{tabular}

With respect to fluorinated species, the switch from third to second-row atoms produced the expected weakening of the interaction. But another distinction between second and third-row atoms was noted for the fluorinated $\mathrm{Me}\left(\mathrm{F}_{3}\right) \mathrm{Ge}$ and $\mathrm{Me}\left(\mathrm{F}_{3}\right) \mathrm{Si}$ acids. Whereas the former pulls in the $\mathrm{NH}_{3}$ to form a short covalent $\mathrm{Ge}-\mathrm{N}$ bond, the same was not true for its $\mathrm{Si}$ analogue wherein $\mathrm{R}(\mathrm{Si} \cdots \mathrm{N})$ remained longer than $3 \AA$. The trend in binding energies of the $\mathrm{F}-\mathrm{H}_{\mathrm{n}} \mathrm{A}$ acids remained halogen $>$ chalcogen $>$ pnicogen $>$ tetrel, as it was for the third-row atoms. However, an exception occured in the consideration of the interaction energy. The very large $(10 \mathrm{~kJ} / \mathrm{mol})$ geometrical distortion energy in $\mathrm{FH}_{3} \mathrm{Si}$ was sufficient to enlarge its interaction energy to exceed that of the pnicogen bond involving $\mathrm{FH}_{2} \mathrm{P}$. 
While the smaller size of the second-row atoms would tend toward shorter intermolecular separations, the weakening of the interactions should have acted to push the two molecules further apart. The values of $\mathrm{R}$ in Table 5 are thus not entirely different from those for the third-row atoms in Table 1. Angular aspects were also generally similar with a few exceptions. The halogen bond of $\mathrm{HCl}$ was distorted from linearity by some $23^{\circ}$, and $\mathrm{MeCl}$ was also less linear than its $\mathrm{MeBr}$ analogue.

\section{Discussion}

In the fully hydrogenated series of Lewis acids, the strengths of the various bonds varied in the pattern chalcogen $>$ halogen $>$ pnicogen $>$ tetrel, although the last two were reversed if the level of calculation was raised from MP2 to $\operatorname{CCSD}(\mathrm{T})$. Note that this pattern did not obey the simple order of electronegativity of the central atom, which would have placed the tetrel bond as strongest. Replacement of one $\mathrm{H}$ atom by a methyl group (opposite the base) weakened all bonds, but had the strongest effect on the halogen bond, which becomes the weakest of the four. Fluorosubstitution very substantially strengthened the four sorts of bonds as the F atom pulled electron density away from the central atom. Leaving one $\mathrm{H}$ atom on the acid to lie opposite the base, and replacing all others by $\mathrm{F}$ strengthened the interactions, and this effect rose with the number of these peripheral $\mathrm{F}$ atoms. Indeed, the three $\mathrm{F}$ atoms of the $\mathrm{HF}_{3} \mathrm{Ge}$ acid enhanced the interaction to the point where the interaction energy exceeded $120 \mathrm{kcal} / \mathrm{mol}$ as the very short tetrel bond acquired a covalent character. The very close approach forced the acid to deform to accommodate the base, but even so, the binding energy of the bonds followed the tetrel > pnicogen > chalcogen pattern, opposite to that observed prior to fluorosubstitution. Replacement of the sole $\mathrm{H}$ atom by a methyl group again weakened the interactions but leaves the ordering intact. A much more profound strengthening effect occurred if it was the $\mathrm{H}$ directly opposite the base that was replaced by $\mathrm{F}$. These interaction energies magnified the unsubstituted interaction energies by a factor between 5 and 9, leading to quantities approaching $70 \mathrm{kcal} / \mathrm{mol}$. It was the halogen bond that was enhanced the most and the tetrel bond the least, so that the order of these monofluorinated bonds washalogen $>$ chalcogen $>$ pnicogen $>$ tetrel. This pattern applied to both interaction and binding energies alike.

The exchange attraction energy was much larger for pnicogen and tetrel bonds than for halogen and chalcogen bonds, making it the largest contributor to the former bond types. With these two exceptions, electrostatics provided the major contribution, surpassing both polarization and dispersion energies by a wide margin. Electrostatic components did not differentiate between the four types of bonds unless there was fluorosubstitution of the Lewis acid. When the F atom was

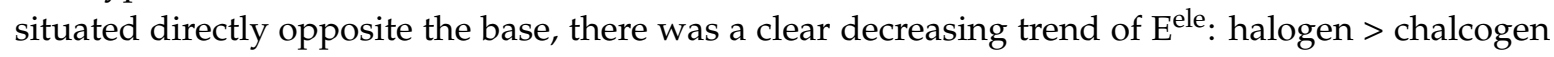
$>$ pnicogen $>$ tetrel. It was also in these same configurations where polarization energy made a major contribution, but was otherwise generally smaller than the dispersion energy. The value of the molecular electrostatic potential at the site of the sigma hole conformed fairly well to the full electrostatic potential. For example, methyl substitution diminished both $\mathrm{E}^{\mathrm{ele}}$ and $\mathrm{V}_{\mathrm{s}, \max }$, and both quantities grew upon fluorosubstitution. The intensity of the $\sigma$-hole was also a good indicator of $E^{\text {ele }}$ in the four sorts of bonds. On the other hand, neither $\mathrm{V}_{\mathrm{s} \text {, max }}$, nor the more complete $\mathrm{E}^{\text {ele }}$, accurately reproduced trends in the full interaction energy. Charge transfer, either measured as the total from one molecule to the other, or specifically from the $\mathrm{N}$ lone pair MO of the base to a $\sigma^{*}$ antibonding orbital of the acid, also provided some guidance in terms of the full interaction energy. For example, both measures correctly predicted the order of bonding for the fluorinated acids. But there are certain inconsistencies as well in that charge transfer was largest for the tetrel bond, but it was the chalcogen bond that was strongest, when considering unsubstituted systems. Similar limitations applied to the density at the AIM bond critical point, which also showed little distinction between the four sorts of bonds in the absence of $\mathrm{F}$ substituents.

There was a general pattern where replacing third-row central atoms with their second-row analogues weakened the various bonds, but this trend was not fully consistent. Taking the non-substituted acids as a case in point, replacement of $\mathrm{Br}$ by $\mathrm{Cl}$ did substantially weaken the halogen bond. However, there was 
little effect on the As to P substitution of the pnicogen bond, and the tetrel bond was strengthened when $\mathrm{Ge}$ was replaced by $\mathrm{Si}$. There was another issue that must be considered as well. While Se was not electronegative enough to engage in a $\mathrm{SeH} \cdots \mathrm{N} \mathrm{H}$-bond with $\mathrm{NH}_{3}$, the more electronegative $\mathrm{S}$ chalcogen atom would form such an $\mathrm{H}$-bond. In fact, the SH$\cdots \mathrm{N} \mathrm{H}$-bond was strong enough that it eliminated the $\mathrm{S} \cdots \mathrm{N}$ chalcogen bond as a secondary minimum on the potential energy surface. The weakening effects of a smaller central atom were more consistently noted, however, when $\mathrm{F}$ atoms were added to the Lewis acid. In the case of peripheral substitutions, there was little distinction between chalcogen and pnicogen bonds for the second-row atoms. Whereas the halogen bond remained strongest when F was placed opposite the base, and chalcogen second, there was a sort of reversal in the other two bonds. While the binding energy of the pnicogen bond exceeded that of the tetrel bond, these two reversed when considering only the interaction energy between pre-deformed monomers. This latter issue arose due to the particularly large deformation energy of the $\mathrm{FH}_{3} \mathrm{Si}$ molecule.

There are a number of works in the recent literature that have some bearing on the comparisons of these various sorts of noncovalent bonds. In a general sense, halogen bonding was found [82] preferable to pnicogen bonding when combined with an amine base, but the order reversed for an aromatic $\pi$-system. On the other hand, pnicogen bonding is more stable than halogen bonding in dimers formed by $\mathrm{HArF}$ and $\mathrm{XH}_{2} \mathrm{P}$ [83]. In broadening the conversation to include chalcogen bonds, Shukla and Chopra [84] investigated how the substituents on the $\mathrm{PH}_{2} \mathrm{R}$ and SeHR molecules determine the structure of the dimer, and thereby the presence of either a pnicogen or chalcogen bond, given the Se...P contact in both. Li and coworkers [85] compared chalcogen with halogen bonds for the fluorosubstituted $\mathrm{F}_{2} \mathrm{C}=$ Se and found the latter to be stronger. However, the comparison was clouded by the different geometries adopted by the two sorts of dimers, one employing a $\sigma$-hole and the other a $\pi$-hole above the Se atom.

The Esrafili group has produced some relevant work as well. One study [86] compared chalcogen with pnicogen bonds, both of which could occur, depending upon the molecular orientations, in RHS: $\mathrm{PH}_{2} \mathrm{R}$ dimers. The authors found only small differences, with interaction energies generally in the range between 8 and $18 \mathrm{~kJ} / \mathrm{mol}$. Halogen bonds were compared with their pnicogen counterparts [87] in the context of hypervalent $\mathrm{ZOF}_{2} \mathrm{X}$ molecules wherein $\mathrm{NH}_{3}$ could interact with either the pnicogen $(Z)$ or halogen $(X)$ atom. A shift from pnicogen to halogen bond preference was observed, consistent with the fact that the halogen bond strengthens as $X$ becomes larger, and the opposite occurs for the X-P..N pnicogen bond. Similar trends were seen in the comparison of halogen with chalcogen bonds for the related $\mathrm{YO}_{2} \mathrm{X}_{2}$ acids [88].

Jiao et al. [89] found halogen bonds considerably stronger than pnicogen bonds, but only in a specialized set of dimers, namely dihalogens combined with phosphine derivatives $\mathrm{PH}_{2} \mathrm{R} \cdots \mathrm{BrX}$. Grabowski and Sokalski [36] considered $\mathrm{NH}_{3}$ as the Lewis base, along with $\mathrm{C}_{2} \mathrm{H}_{2}$ and $\mathrm{Cl}^{-}$. In the case of the former, combined with acids wherein a single F substituent was disposed opposite the base, the order noted for third-row atoms was halogen $>$ chalcogen $>$ pnicogen $>$ tetrel, the same order as obtained here, as are the numerical values. This order persisted for second-row atoms. Shifting gears toward an anionic electron donor, Matile at al [90] have very recently calculated binding energies of various highly fluorinated Lewis acids to $\mathrm{Cl}^{-}$, and found pnicogen bonding stronger than chalcogen bonding, and that fourth row atoms engaged in stronger bonds than their third-row analogues. In all cases, it was a $\mathrm{C}$ atom (of a phenyl ring) that is situated opposite the base, rather than $\mathrm{F}$.

There have also been a number of works from this laboratory that relate to the issue of these comparisons. An early set of calculations [91] suggested a pnicogen $>$ halogen $>$ chalcogen bond strength order, but this work was limited to unsubstituted hydrides that were only weakly bound. HSX molecules, capable of both halogen and chalcogen bonds, yielded mixed results depending upon the nature of the $X$ atom [92]. Whether considering a pnicogen, chalcogen, or halogen bond, all display similar sensitivity to stretching [60,93], but greater sensitivity to angular deformation [94], than do $\mathrm{H}$-bonds. However, there is little to distinguish one from another, and all three are subject to similar substituent effects [95], which follow the general pattern $\mathrm{CH}_{3}<\mathrm{NH}_{2}<\mathrm{CF}_{3}<\mathrm{OH}<\mathrm{Cl}<\mathrm{NO}_{2}<\mathrm{F}$. 
Addition of positive charge on the electron acceptor strengthens all of these interactions, but has more of an effect upon a S...O chalcogen than a C ...O tetrel bond, leading to a preference for the former [64]. Within the specialized context of bipodal receptors that engage in a pair of simultaneous noncovalent bonds with a halide [96-98], tetrel bonding has a clear edge over halogen, chalcogen, and pnicogen bonds. In another specialized context of hypervalency [99], pnicogen bonds show a clear edge over both chalcogen and halogen bonds.

\section{Conclusions}

In the absence of any replacements of $\mathrm{H}$ atoms, the chalcogen bond is the strongest followed in order by halogen, pnicogen, and tetrel. Methyl substitution on the Lewis acid weakens all bonds, particularly the halogen bond, which is the weakest of the four in this bonding environment. All bonds are strengthened by fluorosubstitution (peripheral to, rather than opposite the base), which leads to the bonding order: tetrel $>$ pnicogen $>$ chalcogen. The most dramatic bond enhancement arises from replacement of the atom opposite the base by F, and yet a different order of halogen $>$ chalcogen $>$ pnicogen $>$ tetrel. If the third-row Lewis acid atoms are replaced by their second-row analogues, there is a general weakening of the noncovalent bonds, but this change is not consistent from one sort of bond to the next.

Supplementary Materials: The following are available online. Optimized coordinates of complexes and monomers.

Author Contributions: S.S. conceived of the idea for this project and wrote a first draft of the manuscript; W.D. carried out the calculations and compiled the data; Q.L. supervised the calculations and helped with a final draft.

Funding: This research was funded by the National Natural Science Foundation of China grant number 21573188. Acknowledgments: APC was sponsored by MDPI.

Conflicts of Interest: The author declares no conflict of interest.

\section{References}

1. Lommerse, J.P.M.; Stone, A.J.; Taylor, R.; Allen, F.H. The nature and geometry of intermolecular interactions between halogens and oxygen or nitrogen. J. Am. Chem. Soc. 1996, 118, 3108-3116. [CrossRef]

2. Alkorta, I.; Rozas, S.; Elguero, J. Charge-transfer complexes between dihalogen compounds and electron donors. J. Phys. Chem. A 1998, 102, 9278-9285. [CrossRef]

3. Farina, A.; Meille, S.V.; Messina, M.T.; Metrangolo, P.; Resnati, G.; Vecchio, G. Resolution of racemic 1,2-dibromohexafluoropropane through halogen-bonded supramolecular helices. Angew. Chem. Int. Ed. Engl. 1999, 38, 2433-2436. [CrossRef]

4. Wash, P.L.; Ma, S.; Obst, U.; Rebek, J. Nitrogen-halogen intermolecular forces in solution. J. Am. Chem. Soc. 1999, 121, 7973-7974. [CrossRef]

5. Legon, A.C. Prereactive complexes of dihalogens XY with Lewis bases B in the gas phase: A systematic

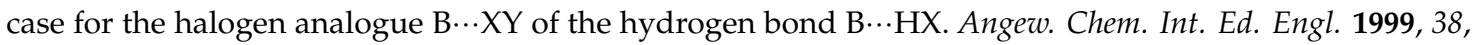
2686-2714. [CrossRef]

6. Caronna, T.; Liantonio, R.; Logothetis, T.A.; Metrangolo, P.; Pilati, T.; Resnati, G. Halogen bonding and $\pi \cdots \pi$ stacking control reactivity in the solid state. J. Am. Chem. Soc. 2004, 126, 4500-4501. [CrossRef] [PubMed]

7. Auffinger, P.; Hays, F.A.; Westhof, E.; Ho, P.S. Halogen bonds in biological molecules. Proc. Natl. Acad. Sci. USA 2004, 101, 16789-16794. [CrossRef] [PubMed]

8. Glaser, R.; Chen, N.; Wu, H.; Knotts, N.; Kaupp, M. ${ }^{13} \mathrm{C}$ NMR study of halogen bonding of haloarenes: Measurements of solvent effects and theoretical analysis. J. Am. Chem. Soc. 2004, 126, 4412-4419. [CrossRef] [PubMed]

9. Grabowski, S.J.; Bilewicz, E. Cooperativity halogen bonding effect-Ab initio calculations on $\mathrm{H}_{2} \mathrm{CO} \cdots(\mathrm{ClF})_{\mathrm{n}}$ complexes. Chem. Phys. Lett. 2006, 427, 51-55. [CrossRef]

10. Riley, K.E.; Merz, K.M. Insights into the strength and origin of halogen bonding: The halobenzene-formaldehyde dimer. J. Phys. Chem. A 2007, 111, 1688-1694. [CrossRef] [PubMed]

11. Politzer, P.; Lane, P.; Concha, M.C.; Ma, Y.; Murray, J.S. An overview of halogen bonding. J. Mol. Model. 2007, 13, 305-311. [CrossRef] [PubMed] 
12. Clark, T.; Hennemann, M.; Murray, J.S.; Politzer, P. Halogen bonding: The $\sigma$-hole. J. Mol. Model. 2007, 13, 291-296. [CrossRef] [PubMed]

13. Rosenfield, R.E.; Parthasarathy, R.; Dunitz, J.D. Directional preferences of nonbonded atomic contacts with divalent sulfur. 1. Electrophiles and nucleophiles. J. Am. Chem. Soc. 1977, 99, 4860-4862. [CrossRef]

14. Row, T.N.G.; Parthasarathy, R. Directional preferences of nonbonded atomic contacts with divalent sulfur in

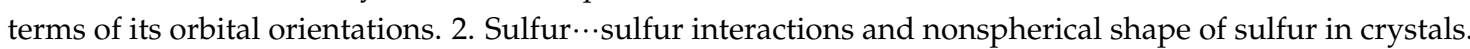
J. Am. Chem. Soc. 1981, 103, 477-479. [CrossRef]

15. Desiraju, G.R.; Nalini, V. Database analysis of crystal-structure-determininginteractions involving sulphur: Implications for the design of organic metals. J. Mater. Chem. 1991, 1, 201-203. [CrossRef]

16. Burling, F.T.; Goldstein, B.M. Computational studies of nonbonded sulfur-oxygen and selenium-oxygen interactions in the thiazole and selenazole nucleosides. J. Am. Chem. Soc. 1992, 114, 2313-2320. [CrossRef]

17. Iwaoka, M.; Tomoda, S. Nature of the intramolecular Se $\cdots \mathrm{N}$ nonbonded interaction of 2-selenobenzylamine derivatives. An experimental evaluation by ${ }^{1} \mathrm{H},{ }^{77} \mathrm{Se}$, and ${ }^{15} \mathrm{~N}$ NMR spectroscopy. J. Am. Chem. Soc. 1996, 118, 8077-8084. [CrossRef]

18. Werz, D.B.; Gleiter, R.; Rominger, F. Nanotube formation favored by chalcogen-chalcogen interactions. J. Am. Chem. Soc. 2002, 124, 10638-10639. [CrossRef] [PubMed]

19. Sanz, P.; Mó, O.; Yáñez, M. Characterization of intramolecular hydrogen bonds and competitive chalcogen-chalcogen interactions on the basis of the topology of the charge density. Phys. Chem. Chem. Phys. 2003, 5, 2942-2947. [CrossRef]

20. Bleiholder, C.; Werz, D.B.; Koppel, H.; Gleiter, R. Theoretical investigations on chalcogen-chalcogen interactions: What makes these nonbonded interactions bonding? J. Am. Chem. Soc. 2006, 128, 2666-2674. [CrossRef] [PubMed]

21. Nziko, V.d.P.N.; Scheiner, S. Chalcogen bonding between tetravalent $\mathrm{SF}_{4}$ and amines. J. Phys. Chem. A 2014, 118, 10849-10856. [CrossRef] [PubMed]

22. Klinkhammer, K.W.; Pyykko, P. Ab initio interpretation of the closed-shell intermolecular E $\cdots E$ attraction in dipnicogen $\left(\mathrm{H}_{2} \mathrm{E}-\mathrm{EH}_{2}\right)_{2}$ and $(\mathrm{HE}-\mathrm{EH})_{2}$ hydride model dimers. Inorg. Chem. 1995, 34, 4134-4138. [CrossRef]

23. Deiters, J.A.; Holmes, R.R. Ab initio treatment of a phosphorus coordinate, trigonal bipyramidal to pentafluoride-pyridine reaction square pyramidal to octahedral. Phosphorus Sulfur Sillicon Relat. Elem. 1997, 123, 329-340. [CrossRef]

24. Scheiner, S. The pnicogen bond: Its relation to hydrogen, halogen, and other noncovalent bonds. Acc. Chem. Res. 2013, 46, 280-288. [CrossRef] [PubMed]

25. Hill, N.J.; Levason, W.; Reid, G. Arsenic (III) halide complexes with phosphine and arsine co-ligands: Synthesis, spectroscopic and structural properties. J. Chem. Soc. Dalton Trans. 2002, 1188-1192. [CrossRef]

26. Scheiner, S. Effects of multiple substitution upon the P...N noncovalent interaction. Chem. Phys. 2011, 387, 79-84. [CrossRef]

27. Scheiner, $\mathrm{S}$. Can two trivalent $\mathrm{N}$ atoms engage in a direct $\mathrm{N} \cdots \mathrm{N}$ noncovalent interaction? Chem. Phys. Lett. 2011, 514, 32-35. [CrossRef]

28. Rossi, A.R.; Jasinski, J.M. Theoretical studies of neutral silane-ammonia adducts. Chem. Phys. Lett. 1990, 169, 399-404. [CrossRef]

29. Ruoff, R.S.; Emilsson, T.; Jaman, A.I.; Germann, T.C.; Gutowsky, H.S. Rotational spectra, dipole moment, and structure of the $\mathrm{SiF}_{4}-\mathrm{NH}_{3}$ dimer. J. Chem. Phys. 1992, 96, 3441-3446. [CrossRef]

30. Schoeller, W.W.; Rozhenko, A. Pentacoordination at fluoro-substituted silanes by weak Lewis donor addition. Eur. J. Inorg. Chem 2000, 2000, 375-381. [CrossRef]

31. Politzer, P.; Murray, J.S.; Lane, P.; Concha, M.C. Electrostatically driven complexes of $\mathrm{SiF}_{4}$ with amines. Int. J. Quantum Chem. 2009, 109, 3773-3780. [CrossRef]

32. Bauzá, A.; Mooibroek, T.J.; Frontera, A. Tetrel bonding interactions. Chem. Rec. 2016, 16, 473-487. [CrossRef] [PubMed]

33. Marín-Luna, M.; Alkorta, I.; Elguero, J. A theoretical study of the $\mathrm{H}_{\mathrm{n}} \mathrm{F}_{4-\mathrm{n}} \mathrm{Si}$ :N-base $(\mathrm{n}=1-4)$ tetrel-bonded complexes. Theor. Chem. Acc. 2017, 136, 41. [CrossRef]

34. Geboes, Y.; De Proft, F.; Herrebout, W.A. Effect of fluorination on the competition of halogen bonding and hydrogen bonding: Complexes of fluoroiodomethane with dimethyl ether and trimethylamine. J. Phys. Chem. A 2017, 121, 4180-4188. [CrossRef] [PubMed] 
35. An, X.; Yang, X.; Xiao, B.; Cheng, J.; Li, Q. Comparison of hydrogen and halogen bonds between dimethyl sulfoxide and hypohalous acid: Competition and Cooperativity. Mol. Phys. 2017, 115, 1614-1623. [CrossRef]

36. Grabowski, S.J.; Sokalski, W.A. Are various $\sigma$-hole bonds steered by the same mechanisms? ChemPhysChem 2017, 18, 1569-1577. [CrossRef] [PubMed]

37. Karpfen, A. Theoretical characterization of the trends in halogen bonding. In Halogen Bonding. Fundamentals and Applications; Metrangolo, P., Resnati, G., Eds.; Springer: Berlin, Germany, 2008; pp. 1-15.

38. Moilanen, J.; Ganesamoorthy, C.; Balakrishna, M.S.; Tuononen, H.M. Weak interactions between trivalent pnictogen centers: Computational analysis of bonding in dimers $\mathrm{X}_{3} \mathrm{E} \cdots \mathrm{EX}_{3}(\mathrm{E}=$ Pnictogen, $\mathrm{X}=$ Halogen). Inorg. Chem. 2009, 48, 6740-6747. [CrossRef] [PubMed]

39. Legon, A.C. The halogen bond: An interim perspective. Phys. Chem. Chem. Phys. 2010, 12, $7736-7747$. [CrossRef] [PubMed]

40. Zahn, S.; Frank, R.; Hey-Hawkins, E.; Kirchner, B. Pnicogen bonds: A new molecular linker? Chem. Eur. J. 2011, 17, 6034-6038. [CrossRef] [PubMed]

41. Adhikari, U.; Scheiner, S. Comparison of P $\cdots \mathrm{D}(\mathrm{D}=\mathrm{P}, \mathrm{N})$ with other noncovalent bonds in molecular aggregates. J. Chem. Phys. 2011, 135, 184306. [CrossRef] [PubMed]

42. Sánchez-Sanz, G.; Trujillo, C.; Alkorta, I.; Elguero, J. Intermolecular weak interactions in HTeXH dimers $(\mathrm{X}=\mathrm{O}, \mathrm{S}, \mathrm{Se}, \mathrm{Te})$ : Hydrogen bonds, chalcogen-chalcogen contacts and chiral discrimination. ChemPhysChem 2012, 13, 496-503. [CrossRef] [PubMed]

43. Adhikari, U.; Scheiner, S. Effects of carbon chain substituent on the P..N noncovalent bond. Chem. Phys. Lett. 2012, 536, 30-33. [CrossRef]

44. Sánchez-Sanz, G.; Trujillo, C.; Solimannejad, M.; Alkorta, I.; Elguero, J. Orthogonal interactions between nitryl derivatives and electron donors: Pnictogen bonds. Phys. Chem. Chem. Phys. 2013, 15, 14310-14318. [CrossRef] [PubMed]

45. Riley, K.E.; Hobza, P. The relative roles of electrostatics and dispersion in the stabilization of halogen bonds. Phys. Chem. Chem. Phys. 2013, 15, 17742-17751. [CrossRef] [PubMed]

46. Sedlak, R.; Stasyuk, O.A.; Fonseca Guerra, C.; Řezáč, J.; Růžička, A.; Hobza, P. New insight into the nature of bonding in the dimers of Lappert's stannylene and its Ge analogs: A quantum mechanical study. J. Chem. Theory Comput. 2016, 12, 1696-1704. [CrossRef] [PubMed]

47. Bauzá, A.; Mooibroek, T.J.; Frontera, A. $\sigma$-Hole opposite to a lone pair: Unconventional pnicogen bonding interactions between $\mathrm{ZF}_{3}(\mathrm{Z}=\mathrm{N}, \mathrm{P}, \mathrm{As}$, and $\mathrm{Sb})$ compounds and several donors. ChemPhysChem 2016, 17, 1608-1614. [CrossRef] [PubMed]

48. Shukla, R.; Chopra, D. Understanding the effect of substitution on the formation of S ...F chalcogen bond. J. Chem. Sci. 2016, 128, 1589-1596. [CrossRef]

49. Esrafili, M.D.; Kiani, H.; Mohammadian-Sabet, F. Tuning of carbon bonds by substituent effects: An ab initio study. Mol. Phys. 2016, 114, 3658-3668. [CrossRef]

50. Legon, A.C. Tetrel, pnictogen and chalcogen bonds identified in the gas phase before they had names: Asystematic look at non-covalent interactions. Phys. Chem. Chem. Phys. 2017, 19, 14884-14896. [CrossRef] [PubMed]

51. Robertson, C.C.; Wright, J.S.; Carrington, E.J.; Perutz, R.N.; Hunter, C.A.; Brammer, L. Hydrogen bonding vs. halogen bonding: The solvent decides. Chem. Sci. 2017, 8, 5392-5398. [CrossRef] [PubMed]

52. Liu, M.-X.; Li, Q.-Z.; Scheiner, S. Comparison of tetrel bonds in neutraland protonated complexes of pyridineTF 3 and furanTF $3(\mathrm{~T}=\mathrm{C}, \mathrm{Si}$, and $\mathrm{Ge})$ with $\mathrm{NH}_{3}$. Phys. Chem. Chem. Phys. 2017, 19, 5550-5559. [CrossRef] [PubMed]

53. Grabowski, S.J. Hydrogen bonds, and $\sigma$-hole and $\pi$-hole bonds-Mechanisms protecting doublet and octet electron structures. Phys. Chem. Chem. Phys. 2017, 19, 29742-29759. [CrossRef] [PubMed]

54. Scheiner, S. Detailed comparison of the pnicogen bond with chalcogen, halogen and hydrogen bonds. Int. J. Quantum Chem. 2013, 113, 1609-1620. [CrossRef]

55. Aakeröy, C.B.; Fasulo, M.; Schultheiss, N.; Desper, J.; Moore, C. Structural competition between hydrogen bonds and halogen bonds. J. Am. Chem. Soc. 2007, 129, 13772-13773. [CrossRef] [PubMed]

56. Solimannejad, M.; Malekani, M.; Alkorta, I. Cooperativity between the hydrogen bonding and halogen bonding in $\mathrm{F}_{3} \mathrm{CX} \cdots \mathrm{NCH}(\mathrm{CNH}) \cdots \mathrm{NCH}(\mathrm{CNH})$ complexes $(\mathrm{X}=\mathrm{Cl}, \mathrm{Br})$. Mol. Phys. 2011, 109, 1641-1648. [CrossRef] 
57. Del Bene, J.E.; Alkorta, I.; Sanchez-Sanz, G.; Elguero, J. ${ }^{31} \mathrm{P}-31 \mathrm{P}$ Spin-spin coupling constants for pnicogen homodimers. Chem. Phys. Lett. 2011, 512, 184-187. [CrossRef]

58. Grabowski, S.J. QTAIM characteristics of halogen bond and related interactions. J. Phys. Chem. A 2012, 116, 1838-1845. [CrossRef] [PubMed]

59. Grabowski, S.J. Hydrogen and halogen bonds are ruled by the same mechanisms. Phys. Chem. Chem. Phys. 2013, 15, 7249-7259. [CrossRef] [PubMed]

60. Scheiner, S. Sensitivity of noncovalent bonds to intermolecular separation: Hydrogen, halogen, chalcogen, and pnicogen bonds. CrystEngComm 2013, 15, 3119-3124. [CrossRef]

61. Riley, K.E.; Rezác, J.; Hobza, P. Competition between halogen, dihalogen and hydrogen bonds in bromo- and iodomethanol dimers. J. Mol. Model. 2013, 19, 2879-2883. [CrossRef] [PubMed]

62. Tang, Q.; Li, Q. Interplay between tetrel bonding and hydrogen bonding interactions in complexes involving $\mathrm{F}_{2} \mathrm{XO}(\mathrm{X}=\mathrm{C}$ and $\mathrm{Si})$ and HCN. Comput. Theor. Chem. 2014, 1050, 51-57. [CrossRef]

63. McDowell, S.A.C.; Holder, Z.L. Computational study of non-covalent interactions in oxirane $\cdots$ XF complexes ( $\mathrm{X}=\mathrm{H}, \mathrm{F}, \mathrm{Cl}, \mathrm{Br}, \mathrm{Li}$ ) and their F-/Li-substituted analogues. Mol. Phys. 2015, 113, 3757-3766. [CrossRef]

64. Scheiner, S. Comparison of $\mathrm{CH} \cdots \mathrm{O}, \mathrm{SH} \cdots \mathrm{O}$, chalcogen, and tetrel bonds formed by neutral and cationic sulfur-containing compounds. J. Phys. Chem. A 2015, 119, 9189-9199. [CrossRef] [PubMed]

65. Alkorta, I.; Del Bene, J.; Elguero, J. $\mathrm{H}_{2} \mathrm{XP}: \mathrm{OH}_{2}$ Complexes: Hydrogen vs. pnicogen bonds. Crystals 2016, 6, 19. [CrossRef]

66. Fanfrlík, J.; Holub, J.; Růžičková, Z.; Řezáč, J.; Lane, P.D.; Wann, D.A.; Hnyk, D.; Růžička, A.; Hobza, P. Competition between halogen, hydrogen and dihydrogen bonding in brominated carboranes. ChemPhysChem 2016, 17, 3373-3376. [CrossRef] [PubMed]

67. Azofra, L.M.; Scheiner, S. Tetrel, chalcogen, and $\mathrm{CH} \cdots \mathrm{O}$ hydrogen bonds in complexes pairing carbonyl-containing molecules with 1, 2, and 3 molecules of $\mathrm{CO}_{2}$. J. Chem. Phys. 2015, 142, 034307. [CrossRef] [PubMed]

68. Domagała, M.; Lutyńska, A.; Palusiak, M. Halogen bond versus hydrogen bond: The many-body interactions approach. Int. J. Quantum Chem. 2017, 117, e25348. [CrossRef]

69. Sánchez-Sanz, G.; Alkorta, I.; Elguero, J. Theoretical study of intramolecular interactions in peri-substituted naphthalenes: Chalcogen and hydrogen bonds. Molecules 2017, 22, 227. [CrossRef] [PubMed]

70. Zhao, C.; Lu, Y.; Zhu, Z.; Liu, H. Theoretical exploration of halogen bonding interactions in the complexes of novel nitroxide radical probes and comparison with hydrogen bonds. J. Phys. Chem. A 2018, 122, 5058-5068. [CrossRef] [PubMed]

71. Dunning, T.H.J. Gaussian basis sets for use in correlated molecular calculations. I. The atoms boron through neon and hydrogen. J. Chem. Phys. 1989, 90, 1007-1023. [CrossRef]

72. Woon, D.E.; Dunning, T.H., Jr. Gaussian basis sets for use in correlated molecular calculations. V. Core-valence basis sets for boron through neon. J. Chem. Phys. 1995, 103, 4572-4585. [CrossRef]

73. Frisch, M.J.; Trucks, G.W.; Schlegel, H.B.; Scuseria, G.E.; Robb, M.A.; Cheeseman, J.R.; Scalmani, G.; Barone, V.; Mennucci, B.; Petersson, G.A.; et al. Gaussian 09; Revision B.01; Gaussian Inc.: Wallingford, CT, USA, 2009.

74. Boys, S.F.; Bernardi, F. The calculation of small molecular interactions by the differences of separate total energies. Some procedures with reduced errors. Mol. Phys. 1970, 19, 553-566. [CrossRef]

75. Latajka, Z.; Scheiner, S. Primary and secondary basis set superposition error at the SCF and MP2 levels: $\mathrm{H}_{3} \mathrm{~N}-\mathrm{Li}^{+}$and $\mathrm{H}_{2} \mathrm{O}-\mathrm{Li}^{+}$. J. Chem. Phys. 1987, 87, 1194-1204. [CrossRef]

76. Bulat, F.A.; Toro-Labbé, A.; Brinck, T.; Murray, J.S.; Politzer, P. Quantitative analysis of molecular surfaces: Areas, volumes, electrostatic potentials and average local ionization energies. J. Mol. Model. 2010, 16, 1679-1691. [CrossRef] [PubMed]

77. Reed, A.E.; Curtiss, L.A.; Weinhold, F. Intermolecular interactions from a natural bond orbital, donor-acceptor viewpoint. Chem. Rev. 1988, 88, 899-926. [CrossRef]

78. Bader, R.F.W. Atoms in Molecules, A Quantum Theory; Clarendon Press: Oxford, UK, 1990; p. 438.

79. Bader, R.F.W. AIM2000; 2.0; McMaster University: Hamilton, ON, Canada, 2000.

80. Su, P.; Li, H. Energy decomposition analysis of covalent bonds and intermolecular interactions. J. Chem. Phys. 2009, 131, 014102. [CrossRef] [PubMed]

81. Schmidt, M.W.; Baldridge, K.K.; Boatz, J.A.; Elbert, S.T.; Gordon, M.S.; Jensen, J.H.; Koseki, S.; Matsunaga, N.; Nguyen, K.A.; Su, S.; et al. General atomic and molecular electronic structure system. J. Comput. Chem. 1993, 14, 1347-1363. [CrossRef] 
82. Bauzá, A.; Quiñonero, D.; Deyà, P.M.; Frontera, A. Halogen bonding versus chalcogen and pnicogen bonding: Acombined Cambridge structural database and theoretical study. CrystEngComm 2013, 15, 3137-3144. [CrossRef]

83. Liu, X.; Cheng, J.; Li, Q.; Li, W. Competition of hydrogen, halogen, and pnicogen bonds in the complexes of HArF with $\mathrm{XH}_{2} \mathrm{P}(\mathrm{X}=\mathrm{F}, \mathrm{Cl}$, and Br). Spectrochim. Acta A Mol. Biomol. Spectrosc. 2013, 101, 172-177. [CrossRef] [PubMed]

84. Shukla, R.; Chopra, D. "Pnicogen bonds" or "chalcogen bonds": Exploiting the effect of substitution on the formation of P...Se noncovalent bonds. Phys. Chem. Chem. Phys. 2016, 18, 13820-13829. [CrossRef] [PubMed]

85. Guo, X.; An, X.; Li, Q. Se $\cdots \mathrm{N}$ Chalcogen bond and Se $\cdots X$ halogen bond involving $\mathrm{F}_{2} \mathrm{C}=$ Se: Influence of hybridization, substitution, and cooperativity. J. Phys. Chem. A 2015, 119, 3518-3527. [CrossRef] [PubMed]

86. Esrafili, M.D.; Akhgarpour, H. An ab initio study on competition between pnicogen and chalcogen bond interactions in binary XHS: $\mathrm{PH}_{2} \mathrm{X}$ complexes $\left(\mathrm{X}=\mathrm{F}, \mathrm{Cl}, \mathrm{CCH}, \mathrm{COH}, \mathrm{CH}_{3}, \mathrm{OH}, \mathrm{OCH}_{3}\right.$ and $\left.\mathrm{NH}_{2}\right)$. Mol. Phys. 2016, 114, 1847-1855. [CrossRef]

87. Esrafili, M.D.; Mohammadirad, N. Characterization of $\sigma$-hole interactions in 1:1 and 1:2 complexes of $\mathrm{YOF}_{2} \mathrm{X}$ $(\mathrm{X}=\mathrm{F}, \mathrm{Cl}, \mathrm{Br}, \mathrm{I} ; \mathrm{Y}=\mathrm{P}, \mathrm{As})$ with ammonia: Competition between halogen and pnicogen bonds. Struct. Chem. 2016, 27, 939-946. [CrossRef]

88. Esrafili, M.D.; Mohammadian-Sabet, F. $\sigma$-Hole bond tunability in $\mathrm{YO}_{2} \mathrm{X}_{2}: \mathrm{NH}_{3}$ and $\mathrm{YO}_{2} \mathrm{X}_{2}: \mathrm{H}_{2} \mathrm{O}$ complexes $(\mathrm{X}=\mathrm{F}, \mathrm{Cl}, \mathrm{Br} ; \mathrm{Y}=\mathrm{S}$, Se): Trends and theoretical aspects. Struct. Chem. 2016, 27, 617-625. [CrossRef]

89. Jiao, Y.; Liu, Y.; Zhao, W.; Wang, Z.; Ding, X.; Liu, H.; Lu, T. Theoretical study on the interactions of halogen-bonds and pnicogen-bonds in phosphine derivatives with $\mathrm{Br}_{2}, \mathrm{BrCl}$, and $\mathrm{BrF}$. Int. J. Quantum Chem. 2017, 117, e25443. [CrossRef]

90. Benz, S.; Poblador-Bahamonde, A.I.; Low-Ders, N.; Matile, S. Catalysis with pnictogen, chalcogen, and halogen bonds. Angew. Chem. Int. Ed. 2018, 57, 5408-5412. [CrossRef] [PubMed]

91. Scheiner, S. On the properties of $\mathrm{X} \cdots \mathrm{N}$ noncovalent interactions for first-, second- and third-row $\mathrm{X}$ atoms. J. Chem. Phys. 2011, 134, 164313. [CrossRef] [PubMed]

92. Adhikari, U.; Scheiner, S. The S $\cdots$ N noncovalent interaction: Comparison with hydrogen and halogen bonds. Chem. Phys. Lett. 2011, 514, 36-39. [CrossRef]

93. Nepal, B.; Scheiner, S. Long-range behavior of noncovalent bonds. Neutral and charged H-bonds, pnicogen, chalcogen, and halogen bonds. Chem. Phys. 2015, 456, 34-40. [CrossRef]

94. Adhikari, U.; Scheiner, S. Sensitivity of pnicogen, chalcogen, halogen and H-bonds to angular distortions. Chem. Phys. Lett. 2012, 532, 31-35. [CrossRef]

95. Adhikari, U.; Scheiner, S. Substituent effects on $\mathrm{Cl} \cdots \mathrm{N}, \mathrm{S} \cdots \mathrm{N}$, and P $\cdots \mathrm{N}$ noncovalent bonds. J. Phys. Chem. A 2012, 116, 3487-3497. [CrossRef] [PubMed]

96. Scheiner, S. Assembly of effective halide receptors from components. Comparing hydrogen, halogen, and tetrel bonds. J. Phys. Chem. A 2017, 121, 3606-3615. [CrossRef] [PubMed]

97. Scheiner, S. Highly selective halide receptors based on chalcogen, pnicogen, and tetrel bonds. Chem. Eur. J. 2016, 22, 18850-18858. [CrossRef] [PubMed]

98. Scheiner, S. Comparison of halide receptors based on $\mathrm{H}$, halogen, chalcogen, pnicogen, and tetrel bonds. Faraday Discuss. Chem. Soc. 2017, 203, 213-226. [CrossRef] [PubMed]

99. Scheiner, S.; Lu, J. Halogen, chalcogen, and pnicogen bonding involving hypervalent atoms. Chem. Eur. J. 2018, 24, 8167-8177. [CrossRef] [PubMed]

Sample Availability: Sample Availability: Not available. 